\title{
PENGARUH METODE PENGOLAHAN DAN WAKTU PEMERAMAN TERHADAP KUALITAS NUTRISI PELEPAH SAWIT SEBAGAI BAHAN PAKAN TERNAK KERBAU RAWA (Buffelus asiaticus)
}

\author{
The Effect of Processing Method and Curing Time on Nutrition Quality of Oil Palm Fronds \\ as Feed of Swamp Buffalo (Buffelus asiaticus)
}

\author{
Judo Laksono*, Wasir Ibrahim \\ Department of Animal Husbandry, University of Musi Rawas \\ Jl. Sultan Mahmud Badaruddin II, Air Kuti, Lubuk Linggau Tim. I, Lubuklinggau, \\ Sumatera Selatan 31625 \\ *E-mail: judolaksono@gmail.com
}

Submitted : December 5, $2019 \quad$ Accepted : March 27, 2020

\begin{abstract}
ABSTRAK
Penelitian ini bertujuan untuk mengevaluasi kualitas nutrisi ( $\mathrm{pH}$, kadar air, bahan kering, protein kasar dan serat kasar) pelepah sawit sebagai bahan pakan ternak Kerbau Rawa (Buffelus asiaticus). Rancangan penelitian yang digunakan adalah Rancangan Acak Lengkap (RAL) dengan pola faktorial (3x3). Faktor pertama terdiri dari metode pengolahan amoniasi (P1), silase (P2), dan fermentasi (P3). Faktor kedua waktu pemeraman yang terdiri dari 18 hari (W1), 21 hari (W2), dan 24 hari (W3). Total unit percobaan sebanyak 27 unit. Hasil penelitian yang didapat dianalisis menggunakan analisis sidik ragam (Analysis of Variance/ANOVA) dan dilanjutkan dengan uji Jarak Berganda Duncan. Hasil penelitian menunjukkan bahwa tidak terdapat interaksi antara metode pengolahan dan waktu pemeraman terhadap kualitas nutrisi pelepah sawit. Hasil penelitian menunjukkan bahwa metode pengolahan dan lama waktu pemeraman pelepah sawit sebagai pakan ternak Kerbau Rawa (Buffelus asiaticus) sangat berpengaruh nyata $(\mathrm{P}<0,01)$ pada $\mathrm{pH}$, kadar air, dan bahan kering dan berpengaruh nyata $(\mathrm{P}<0,05)$ pada protein kasar dan serat kasar. Metode pengolahan pelepah sawit secara fermentasi memberikan hasil terbaik pada penurunan $\mathrm{pH}$, peningkatan kandungan protein kasar dan serat kasar serta waktu pemeraman selama 24 hari memberikan hasil terbaik pada penurunan kadar air dan peningkatan bahan kering yang menunjukkan tingginya pertumbuhan mikroorganisme pengurai dalam proses pengolahan pelepah sawit untuk meningkatkan kualitas nutrisi pelepah sawit sebagai bahan pakan ternak Kerbau Rawa (Buffelus asiaticus).
\end{abstract}

Kata Kunci: Amoniasi, Fermentasi, Pelepah sawit, Silase, Waktu pemeraman.

\section{ABSTRACT}

The objectives of this study were to evaluate feed nutrition quality ( $p H$, water content, dry ingredients, crude protein and crude fiber) of oil pam fronds as feed of Swamp Buffalo (Buffelus asiaticus). The experimental design used was Completely Randomized Design (CRD) with factorial esperiment $(3 x$ 3). First factor consisted of ammonia processing method (P1), Silage (P2), and fermentation (P3). Second factor was curing time consisted of 18 days (W1), 21 days (W2), and 24 days (W3). Each treatment combination was replicated three replications, so that there were 27 experimental units. The result were analyzed using Analysis of Variance (ANOVA) and continued by Duncan Multiple Range test. The result showed that there was no interaction between processing methods and curing time on the nutritional quality of the oil palm fronds. The result processing methods and curing time of oil palm fronds as feed nutrition of Swamp Buffalo (Buffelus asiaticus) at this study significantly affected $(P<0.01)$ on $\mathrm{pH}$, moisture content, dry matter content and significantly affected $(P<0.05)$ on crude protein and crude fiber content. Processing method with fermentation of oil palm fronds gave the best results in decreasing $\mathrm{pH}$, increasing the content of crude protein and crude fiber and also 24 days curing time gave the best results in decreasing moisture content and increasing dry matter content which showed the high growth of decomposing microorganisms in the processing of oil palm fronds indicating the increase the feed nutrition quality of oil palm fronds as feed of Swamp Buffalo (Buffelus asiaticus).

Keywords: Ammonia, Curing time, Fermentation, Silage, Oil palm fronds. 


\section{PENDAHULUAN}

Kerbau Rawa (Buffelus asiaticus) adalah salah satu dari beberapa ternak ruminansia yang dapat hidup di daerah rawa. Kerbau Rawa di Indonesia tersebar di pulau Sumatera dan Kalimantan. Ternak ini selain berfungsi sebagai sumber pangan juga sebagai pekerja dan ternak yang dapat mengkonsumsi pakan dengan kualitas rendah (Ali et al., 2013; Wanapat et al., 2016).

Jumlah populasi ternak kerbau di Indonesia tahun 2017 adalah 1.321.904 ekor dan tahun 2018 adalah 1.356.390 ekor. Populasi ternak kerbau di Provinsi Sumatera Selatan tahun 2017 sebanyak 30.840 ekor dan tahun 2018 sebanyak 32.820 ekor. Hal ini menunjukkan populasi ternak Kerbau Rawa khususnya di Sumatera Selatan mengalami kenaikan sebanyak 1.980 ekor (Kementerian Pertanian, 2016).

Peningkatan populasi Kerbau Rawa di Sumatera Selatan disebabkan karena pemeliharaan yang intensif dan ketersediaan kebutuhan pakan ternak Kerbau Rawa sepanjang tahun sehingga pengembangan ternak ruminansia berjalan dengan baik. Penyediaan pakan secara berkelanjutan dengan jumlah cukup dan kualitas cukup baik merupakan faktor yang dapat memberikan pengaruh terhadap produktivitas ternak ruminansia (Laksono dan Karyono, 2017).

Salah satu potensi sumber pakan yang dapat di kembangkan adalah pelepah kelapa sawit dengan produksi mencapai 18-30 pelepah/batang dan rataan bobot pelepah adalah $2,2 \mathrm{~kg}$ sehingga produksi biomasa pelepah kelapa sawit mencapai 6,3 ton/ha. Menurut Widyastuti dan Syabana (2015) jumlah pelepah dan daun segar yang dapat diperoleh untuk setiap hektar kelapa sawit mencapai lebih dari 2,3 ton bahan kering. Kandungan gizi pelepah kelapa sawit terdiri dari bahan kering (BK) 97,39, abu 3,96\%, protein kasar (PK) 2,23\%, serat kasar (SK) 47,00\%, 3,04\% lemak kasar (LK), 76,09 \% NDF, 57,56\% ADF, hemiselulosa 18,51\%, 14,23\% lignin, dan $43,00 \%$ selulosa. Pelepah kelapa sawit terdiri dari daun dan tulang pelepah, pada daun mengandung $\mathrm{N}, \mathrm{K}, \mathrm{P}, \mathrm{Mg}$, Ca dan S, masing-masing 2,05\%, $0,88 \%, \quad 0,13 \%, \quad 0,23 \%, \quad 0,36 \%$ dan $0,17 \%$ sedangkan pada tulang pelepah mengandung $0,37 \%, 1,49 \%, 0,07 \%, 0,19 \%, 0,21 \%$ dan $0,18 \%$ (Corley and Tinker, 2016). Pelepah kelapa sawit memiliki kandungan lignin mencapai $14 \%$ sehingga menjadi faktor pembatas utama kecernaan ternak, maka perlu dilakukan pengolahan terlebih dahulu yang diharapkan dapat memecahkan ikatan lignin, selulosa dan hemislulosa sehingga akan menurunkan kandungan serat. Beberapa cara untuk menurunkan serat kasar tinggi yaitu amoniasi, silase dan fermentasi (Nurhayati et al., 2013). Silase merupakan pengawetan hijauan dalam bentuk segar dengan kandungan air bahan tinggi umumnya lehih dari $50 \%$ dan memanfaatkan bakteri yang ada di dalam tanaman tersebut untuk mengurai dalam keadaan anaerob. Fermentasi merupakan pengawetan bahan pakan yang berasal dari limbah pertanian dengan serat kasar yang cukup tinggi sehingga dapat ditambah inokulum atau mikroba pengurai untuk mempercepat proses fermentasi bahan. Penelitian ini bertujuan untuk mengetahui kualitas nutrisi pelepah sawit terhadap pengolahan dan waktu sebagai hijauan hijauan pakan ternak kerbau rawa (Buffelus asiaticus)

\section{MATERI DAN METODE}

\section{Materi}

Penelitian ini telah dilaksanakan di Laboratorium Fakultas Pertanian Universitas Musi Rawas Kelurahan Lubuklinggau Timur I Kota Lubuklinggau Sumatra Selatan pada ketinggian 93 mdpl. Penelitian berlangsung dari April hingga Juni 2019 menggunakan materi pelepah sawit diambil dari perkebunan rakyat, dedak, urea, molases dari toko pertanian, mol bonggol pisang dibuat sendiri menurut metode Farida et al. (2013) dengan tahapan sebagai berikut: 1) mempersiapkan bahan berupa $1 \mathrm{~kg}$ bonggol pisang, $0,25 \mathrm{~kg}$ gula merah, dan 2 liter air cucian beras, 2) mengiris tipis dan menumbuk bonggol pisang, 3) mengiris tipis gula merah untuk mempermudah dilarutkan dengan air cucian beras, 4) memasukkan bonggol pisang, gula merah dan air cucian beras ke dalam ember dan mengaduk hingga rata, 5) memasukkan campuran semua bahan ke dalam ember ke dalam jerigen 5 liter, pada bagian tutupnya diberi lubang dan selang kecil yang terhubung dengan botol air mineral bekas untuk mengeluarkan sisa-sisa gas hasil, dan 6) memfermentasi selama 15 hari.

Alat-alat yang digunakan adalah mesin chopper blender, timbangan analitik Fujitsu ${ }^{\circledR}$, oven Mamert ${ }^{\circledR}$, plastik, gelas ukur Pyrex $\AA, p H$ meter ATC $®$, dan alat tulis.

\section{Metode}

Metode pengolahan pelepah sawit sebagai berikut: 1) Amoniasi. Perlakuan amoniasi dilakukan dengan cara $1 \mathrm{~kg}$ pelepah sawit yang sudah di chooper di tambah urea 5\% dari berat bahan $(5 \mathrm{~g})+270 \mathrm{ml}$ air. Urea yang telah di campur hingga merata kemudian disiramkan secara perlahan pada pelepah sawit sampai merata hingga kadar air $60 \%$ setelah itu pelepah sawit 
yang sudah tercampur dengan bahan secara merata dimasukan kedalam kantong plastik hingga kedap udara; 2) Silase. Perlakuan silase dilakukan dengan cara mencampur $1 \mathrm{~kg}$ pelepah sawit sudah di chooper ditambahkan dedak padi $10 \%$ dari berat bahan $(100 \mathrm{~g})$ dan molase $3 \%$ dari bahan $(30 \mathrm{ml})+270 \mathrm{ml}$ air. Dedak dan pelepah sawit dicampur merata hingga kadar air $60 \%$. Setelah pelepah sawit yang sudah tercampur rata dimasukan kedalam kantong plastik dan diikat hingga kedap udara; 3) Fermentasi. Perlakuan fermentasi dilakukan dengan cara $1 \mathrm{~kg}$ pelepah sawit sudah di chooper ditambahkan mol bonggol pisang $35 \mathrm{ml} / \mathrm{lt}$, molases $3 \%$ dari bahan $(30 \mathrm{ml})$ dan $270 \mathrm{ml}$ air. Mol bonggol pisang, air dan molases di campurkan secara merata kemudian disiramkan secara berlahan-lahan pada pelepah sawit, setelah di campur merata dengan bahan kemudian dimasukkan kedalam kantong plastik dan diikat hingga kedap udara.

Rancangan penelitian yang digunakan adalah Rancangan Acak Lengkap Faktorial (3x3) yang terdiri dua faktor. Faktor pertama terdiri dari metode pengolahan amoniasi (P1), silase (P2), fermentasi (P3). Faktor kedua waktu pemeraman yang terdiri dari 18 hari (W1), 21 hari (W2), 24 hari (W3). Total unit percobaan sebanyak 27 unit. Data yang diperoleh dianalisis menggunakan analisis sidik ragam (Analysis of Variancel ANOVA) dan dilanjutkan uji Duncan (Gomez dan Gomez, 1995).

\section{HASIL DAN PEMBAHASAN}

Berdasarkan hasil penelitian metode pengolahan dan waktu pemeraman pelepah sawit sebagai pakan ternak Kerbau Rawa (Buffelus asiaticus) sangat berpengaruh nyata $(\mathrm{P}<0,01)$ pada parameter $\mathrm{pH}$, kadar air, bahan kering dan berbeda nyata $(\mathrm{P}<0,05)$ pada parameter protein kasar dan serat kasar sedangkan pada interaksi tidak berpengaruh nyata pada semua parameter pengamatan.

pH

Hasil analisis ragam menunjukan bahwa metode pengolahan $(\mathrm{P})$ sangat berpengaruh nyata $(\mathrm{P}<0,01)$ pada parameter $\mathrm{pH}$, sedangkan waktu pemeraman (W) dan interaksi kedua perlakuan (PW) tidak berpengaruh nyata pada perlakuan $\mathrm{pH}$. Rata-rata tabulasi macam-macam pengolahan dan waktu pemeraman serta interaksi parameter terhadap $\mathrm{pH}$ disajikan pada Tabel 1.

Uji lanjut menunjukkan bahwa perlakuan pada $\mathrm{P} 1$ (amoniasi) sangat berbeda nyata $(\mathrm{P}<0,01)$ dengan P3 (fermentasi) dan berbeda nyata dengan P2 (silase). Berdasarkan data tabulasi hasil rata- rata metode pengolahan $(\mathrm{P})$ menunjukan $\mathrm{pH}$ tertinggi pada perlakuan P1 (amoniasi) yaitu 4,52 sedangkan $\mathrm{pH}$ terendah pada perlakuan P3 (fermentasi) yaitu 3,66. Hal ini diduga karena adanya perbedaan dalam pengolahan pelepah sawit menghasilkan $\mathrm{pH}$ yang berbeda pada setiap pengolahan. Perlakuan P1 proses amoniasi yang merupakan proses pengolahan secara kimia dengan $\mathrm{pH}$ amoniasi yang baik 6,5 - 7 . Pengolahan ini menggunakan bahan kimia berupa urea yang bersifat basah. Pada perlakuan P2 (silase) dan P3 (fermentasi), pH yang dihasilkan dibawah 4,0 yang bersifat asam, sehingga dalam prosesnya melibatkan banyak bakteri asam laktat yang terbentuk dari kondisi anaerob, sesuai pernyataan Sebayang (2006) bahwa keadaan asam pada silase karena adanya oksidasi etanol menjadi asetildehid yang kemudian dioksidasi menjadi asam laktat, kondisi ini akan menyebabkan suasana menjadi asam.

\section{Kadar Air}

Hasil analisis ragam menunjukan bahwa waktu pemeraman (W) sangat berpengaruh nyata $(\mathrm{P}<0,01)$ pada parameter kadar air, sedangkan metode pengolahan $(\mathrm{P})$ dan interaksi kedua perlakuan (PW) tidak berpengaruh nyata pada perlakuan kadar air. Rata-rata tabulasi metode pengolahan dan waktu pemeraman serta interaksi parameter terhadap kadar air disajikan pada Tabel 1.

Uji lanjut menunjukkan bahwa perlakuan pada W3 (24 hari) sangat berbeda nyata $(\mathrm{P}<0,01)$ dengan W1 (18 hari) dan W2 (21 hari). Berdasarkan data tabulasi hasil rata-rata waktu pemeraman $(\mathrm{W})$ menunjukan kadar air tertinggi pada waktu pemeraman 18 hari yaitu $8,20 \%$ sedangkan kadar air terendah pada waktu pemeraman 24 hari yaitu 4,91\%. Hal ini diduga karena adanya perbedaan lama waktu pemeraman menyebabkan kadar air yang di hasilkan berbedabeda karena dalam proses pemeraman, air diperlukan untuk proses pertumbuhan mikroorganisme pengurai, semakin lama waktu pemeraman mengakibatkan semakin banyak air yang digunakan mikroba dalam proses metabolisme penguraian bahan sehingga kandungan air semakin rendah. Raimbault (1998) menyatakan bahwa kadar air media dapat mempengaruhi pertumbuhan mikroorganisme yang dihasilkan karena air merupakan media transpor substrat dan pereaksi pada proses metabolisme mikroorganisme.

\section{Bahan Kering}

Hasil analisis ragam menunjukan bahwa waktu pemeraman (W) sangat berpengaruh nyata 
$(\mathrm{P}<0,01)$ pada parameter bahan kering, sedangkan metode pengolahan (P) dan interaksi kedua perlakuan (PW) tidak berpengaruh nyata pada perlakuan bahan kering. Rata-rata tabulasi metode pengolahan dan waktu pemeraman serta interaksi parameter terhadap bahan kering disajikan pada Tabel 1.

Uji lanjut menunjukkan bahwa perlakuan pada W3 (24 hari) sangat berbeda nyata $(\mathrm{P}<0,01)$ dengan W1 (18 hari) dan tidak berbeda nyata $(\mathrm{P}<0,05)$ dengan W2 (21 hari). Berdasarkan data tabulasi hasil rata-rata waktu pemeraman (W) menunjukan kandungan bahan kering tertinggi pada waktu pemeraman 24 hari yaitu $95,16 \%$ sedangkan kandungan bahan kering terendah pada perlakuan waktu pemeraman 18 hari yaitu 91,84\%. Hal ini diduga karena semakin lama waktu yang digunakan dalam pemeramam menyebabkan bahan kering meningkat, berdasarkan hasil penelitian ini menunjukan bahan kering berkisar 91\% - 95\%. Menurut Alamsyah et al. (2013) kandungan bahan kering yang baik yaitu $92 \%-96 \%$.

\section{Protein Kasar}

Hasil analisis ragam menunjukan bahwa metode pengolahan (P) berpengaruh nyata $(\mathrm{P}<0,05)$ pada parameter protein kasar, sedangkan waktu pemeraman (W) dan interaksi kedua perlakuan (PW) tidak berpengaruh nyata pada perlakuan protein kasar. Rata-rata tabulasi metode pengolahan dan waktu pemeraman serta interaksi parameter terhadap protein kasar disajikan pada Tabel 1.

Tabel 1. Rata-rata tabulasi metode pengolahan (P) dan waktu pemeraman (W) serta interaksi pada tiap parameter penelitian

\begin{tabular}{|c|c|c|c|c|}
\hline Perlakuan & W1 & W2 & W3 & Rerata \\
\hline \multicolumn{5}{|l|}{ pH } \\
\hline $\mathrm{P} 1$ & 4,55 & 4,52 & 4,48 & $4,52^{\mathrm{bB}}$ \\
\hline $\mathrm{P} 2$ & 3,85 & 3,95 & 3,90 & $3,90^{\mathrm{abA}}$ \\
\hline P3 & 3,73 & 3,69 & 3,57 & $3,66^{\mathrm{aA}}$ \\
\hline Rerata & 4,04 & 4,05 & 3,98 & \\
\hline \multicolumn{5}{|l|}{ Kadar Air } \\
\hline $\mathrm{P} 1$ & 7,94 & 5,79 & 4,67 & 6,13 \\
\hline $\mathrm{P} 2$ & 7,89 & 6,11 & 4,91 & 6,30 \\
\hline P3 & 8,78 & 6,26 & 5,16 & 6,73 \\
\hline Rerata & $8,20^{\mathrm{cC}}$ & $6,05^{\mathrm{abAB}}$ & $4,91^{\mathrm{aA}}$ & \\
\hline \multicolumn{5}{|l|}{ Bahan Kering } \\
\hline $\mathrm{P} 1$ & 92,05 & 94,20 & 95,32 & 96,95 \\
\hline $\mathrm{P} 2$ & 92,10 & 93,88 & 95,08 & 96,86 \\
\hline P3 & 91,37 & 93,84 & 95,07 & 96,74 \\
\hline Rerata & $91,84^{\mathrm{aA}}$ & $93,97^{\mathrm{bB}}$ & $95,16^{b B}$ & \\
\hline \multicolumn{5}{|l|}{ Protein Kasar } \\
\hline $\mathrm{P} 1$ & 5,71 & 5,12 & 5,42 & $5,42^{\mathrm{a}}$ \\
\hline $\mathrm{P} 2$ & 4,24 & 5,27 & 4,83 & $4,79^{a}$ \\
\hline P3 & 5,24 & 5,27 & 8,03 & $6,18^{b}$ \\
\hline Rerata & 5,06 & 5,22 & 6,09 & \\
\hline \multicolumn{5}{|l|}{ Serat Kasar } \\
\hline $\mathrm{P} 1$ & 20,44 & 20,18 & 21,14 & $20,59^{a}$ \\
\hline $\mathrm{P} 2$ & 18,46 & 21,37 & 22,20 & $20,68^{a}$ \\
\hline P3 & 21,85 & 22,76 & 21,76 & $22,12^{b}$ \\
\hline Rerata & 20,25 & 21,44 & 21,70 & \\
\hline
\end{tabular}

Keterangan: Huruf superskrip berbeda pada baris atau kolom yang sama menunjukkan berbeda sangat nyata $\{\mathrm{P}<0,01$ (huruf besar) $\}$ dan berbeda nyata $\{\mathrm{P}<0,05$ (huruf kecil) $\}$.

Uji lanjut menunjukkan bahwa perlakuan pada P3 (fermentasi) berbeda nyata $(\mathrm{P}<0,05)$ dengan P2 (silase) dan P1 (amoniasi). Berdasarkan data tabulasi hasil rata-rata metode pemeraman $(\mathrm{P})$ menunjukan kandungan protein kasar tertinggi pada metode pengolahan fermentasi yaitu $6,18 \%$ sedangkan kandungan protein kasar terendah pada perlakuan metode pengolahan silase yaitu $4,79 \%$. Hal ini di duga karena adanya aktivitas fisik, kimia dan biologi yang dilakukan pada metode pengolahan sehingga kandungan pada protein kasar meningkat. Peningkatan ini dapat dilihat dengan membandingkan protein kasar sebelum dilakukan 
pengolahan yaitu $2,32 \%$, setelah di lakukan pengolahan meningkat menjadi $5,42 \%$ (amoniasi), 4,79\% (silase) dan $6,18 \%$ (fermentasi). Peningkatan kandungan protein kasar juga akibat adanya aktivitas fisik yaitu penyacahan dan aktivitas kimia yaitu penambahan urea dan aktifitas biologi dengan penambahan mikroorganisme lokal (MOL) bonggol pisang, yang dilakukan pada sebelum maupun saat pengolahan pelepah sawit. Menurut pendapat Utomo (2015), perlakuan yang diberikan pada hasil sisa tanaman pertanian atau perkebunan, dapat dilakukan pengolahan secara fisik, kima dan biologi untuk meningkatkan kandungan nutrisi

\section{Serat Kasar}

Hasil analisis ragam menunjukkan bahwa metode pengolahan (P) berpengaruh nyata $(\mathrm{P}<0,05)$ pada parameter serat kasar, sedangkan waktu pemeraman (W) dan interaksi kedua perlakuan (PW) berpengaruh tidak nyata pada perlakuan serat kasar. Rata-rata tabulasi metode pengolahan dan waktu pemeraman serta interaksi parameter terhadap serat kasar disajikan pada Tabel 1.

Uji lanjut menunjukkan bahwa perlakuan P3 (fermentasi) berbeda nyata $(\mathrm{P}<0,05)$ dengan P2 (silase) dan P1 (amoniasi). Berdasarkan data tabulasi hasil rata-rata waktu pemeraman (P) menunjukan kandungan serat kasar tertinggi pada metode pengolahan fermentasi yaitu $22,12 \%$ sedangkan kandungan serat kasar terendah pada perlakuan metode pengolahan amoniasi yaitu $20,59 \%$. Hal ini diduga karena adanya kerja enzim maupun mikroba selulotik pada macammacam pengolahan, sehingga proses hidrolisis dari mikroba mampu mendegradasi dan memecahkan ikatan-ikatan lignoselulosa dan lignohemiselulosa, serta melarutkan silika dan lignin yang terdapat dalam dinding sel bahan pakan berserat. Menurut Komar (1984) penurunan kadar serat kasar terjadi karena perlakuan fermentasi yang menyebabkan perubahan dinding sel.

\section{SIMPULAN}

Metode pengolahan pelepah sawit secara fermentasi memberikan hasil terbaik pada penurunan $\mathrm{pH}$, peningkatan kandungan protein kasar dan serat kasar serta waktu pemeraman selama 24 hari memberikan hasil terbaik pada penurunan kadar air dan peningkatan bahan kering yang menunjukkan tingginya pertumbuhan mikroorganisme pengurai dalam proses pengolahan pelepah sawit untuk meningkatkan kualitas pakan ternak Kerbau Rawa (Buffelus asiaticus).

\section{UCAPAN TERIMAKSIH}

Ucapan terima kasih peneliti sampaikan kepada Kementerian Riset, Teknologi dan Pendidikan Tinggi Melalui Hibah Pemula DIKTI 2018.

\section{DAFTAR PUSTAKA}

Ali, A.I.M, S. Sandi, Muhakka, Riswandi, dan D. Budianta. 2013. The Grazing of Pampangan Buffaloes at Non Tidal Swamp in South Sumatra of Indonesia. APCBEE Procedia. 8: 87-92.

Alamsyah, A. A. D., C. Joddy, P. T. Agnes, dan P. Vita. 2013. Pembuatan Pangan Lele Organik Berbahan Baku Protein dari Bulu Ayam dengan Metode Fermentasi Bio. Proseding Seminar Nasional Sain dan Teknologi Ke -4. Semarang.

Corley, R. H. V., and P. B. Tinker. 2016. The Oil Palm. $5^{\text {th }}$ Ed. Wiley Blackwell. United Kingdom.

Direktorat Pengolahan Lahan. 2007. Pedoman Teknis Pengembangan Usaha Tani Padi Sawah Metode System of Rice Intencification (SRI). Direktorat Jendral Pengolahan Lahan dan Air Departemen Pertanian. Jakarta

Farida A, S. Sumiati, dan D. S. Handayani 2013. Studi Perbandingan Pengaruh Penambahan Aktivator Agri Simba dengan MOL Bonggol Pisang terhadap Kandungan Unsur Hara Makro Kompos dari Blotong (Sugarcane Filter Cake) dengan Variasi Penambahan MOL. J. Teknik Lingkungan 3(1): 1-11.

Ginting, S. T. P., dan J. Elizabeth. 2005. Tekonologi Pakan Hasil Sampingan Kelapa Sawit dengan Berbahan Dasar Perkebunan. Lokakarya Sistem Integrasi Kelapa Sawit-Sapi. Pusat Penelitian dan Pengembangan Peternakan. Bogor.

Gomes. K. A., dan A. A. Gomez. 1995. Prosedur Statistik untuk Penelitian. UI Press. Jakarta

Laksono, J., dan T. Karyono. 2017 Pemberian Fosfat dan Fungi Mikoriza Albuskular Terhadap Pertumbuhan Tanaman Legum indigofera zollingeriana. J. Sain Peternakan Indonesia. 12:165-170

Kementerian Pertanian. 2016. Database Pertanian. www.pertanian.go.id (diakses September 2018). 
Komar, A. 1984. Teknologi Pengolahan Jerami Padi Sebagai Pakan Ternak. Dian Grahita. Bandung

Marjuki. 2012. Peningkatan Kualitas Nutrisi Jerami Padi dengan Perlakuan Amoniasi. Artikel Ilmiah. Fakultas Peternakan Universitas Brawijaya. Malang

Nurhayati, T., Y. Mas'udah, dan S. Sarudji. 2013. The Content of Crude Protein and Crude Fiber Palm Oil Fronds Fermented by Xylanolitic Bacteria (Bacillus pumilus) Agroveteriner. 1(2):73-78

Raimbault, M. 1998. General and microbiological aspect of solid subsrate fermentation. Electronic J. Biotechnol. 3:1-5.

Sebayang, F. 2006. Pembuatan Etanol dari Molases secara Fermentasi menggunakan Sel Saccharomyces cerevisiae yang Terimobilisasi pada Kalsium Alginat. $J$. Teknologi Proses. 5(2):75-80.

Utomo, R. 2015. Konservasi Hijauan Pakan Ternak dan Peningkatan Kualitas Bahan Pakan Berserat Tinggi. Gajah Mada University Press. Yogyakarta.

Wanapat, M., K. Phesatcha, and S. Kang. 2016. Rumen Adaptation of Swamp Buffaloes (Bubalusbubalis) by High Level of Urea Supplementation when Fed on Rice StrawBased Diet. Trop Anim Health Prod Journal. 48(6):1135-40

Widyastuti, R., dan D. K. Syabana. 2015. Serat Pelepah Kelapa Sawit (Sepawit) untuk Bahan Baku Produk Kerajinan. Prosiding Seminar Nasional $4^{\text {th }}$ UNS SME's Summit and Awards 2015 Sinergitas Pengembangan UMKM dalam Era Masyarakat Ekonomi ASEAN (MEA). Balai Besar Kerajinan dan Batik. Yogyakarta. 